\title{
PENGARUH PERILAKU BERMAIN VIDEO GAME BERUNSUR KEKERASAN TERHADAP PERILAKU AGRESI REMAJA
}

\section{(Influence Behavior Playing Video Games element Violence Against Adolescent Aggression Behavior)}

\author{
Nadia Itona Siregar ${ }^{1)}$ dan Pudji Muljono ${ }^{1)}$ \\ ${ }^{1)}$ Departemen Sains Komunikasi dan Pengembangan Masyarakat, Fakultas Ekologi Manusia, Institut \\ Pertanian Bogor, Darmaga Bogor 16680, Indonesia \\ Email:nadiasiregar.kpm48@gmail.com; pudjim@apps.ipb.ac.id
}

\begin{abstract}
The development of today's technology so rapidly, this development affects the audio-visual media one of which is video games. The aim of this study are: 1) to analyze the differences influence the level of violent video game playing element to the level of adolescent aggressive behavior, 2) to analyze the influence of personal factors as differences in behavior-forming element violent video games to the level of adolescent aggressive behavior, 3) to analyze differences in the effect of factors situational as forming behavior of violent video game playing element to the level of adolescent aggressive behavior. The analysis in this study uses cross tabulation, the statistical test Mann-Whitney and Kruskal-Wallis with a 5\% significance level. The results showed that there are differences in the level of situational and gender differences on the level of play behavior element violent video games; and there are differences in the level of playing video games behavioral element of violence against adolescent aggressiveness level.
\end{abstract}

Keywords: audio-visual media, development of technology

\begin{abstract}
ABSTRAK
Perkembangan teknologi saat ini begitu pesat, perkembangan ini mempengaruhi media audio-visual salah satunya adalah video game. Tujuan dari penelitian ini adalah: 1) untuk menganalisis perbedaan yang memengaruhi elemen tingkat kekerasan bermain video game ke tingkat perilaku agresif remaja, 2) untuk menganalisis pengaruh faktor pribadi sebagai perbedaan dalam elemen perilaku pembentuk video game kekerasan untuk tingkat perilaku agresif remaja, 3) untuk menganalisis perbedaan pengaruh faktor situasional sebagai pembentuk perilaku bermain video game unsur kekerasan ke tingkat perilaku agresif remaja. Analisis dalam penelitian ini menggunakan tabulasi silang, uji statistik Mann-Whitney dan Kruskal-Wallis dengan tingkat signifikansi 5\%. Hasil penelitian menunjukkan bahwa ada perbedaan dalam tingkat perbedaan situasional dan jenis kelamin pada tingkat perilaku bermain elemen video game kekerasan; dan ada perbedaan dalam tingkat bermain video game unsur perilaku kekerasan terhadap tingkat agresivitas remaja.
\end{abstract}

Kata kunci: media audio-visual, perkembangan teknologi

\section{PENDAHULUAN}

Teknologi merupakan salah satu hal yang paling berpengaruh pada kehidupan masyarakat saat ini. Perkembangan teknologi yang pesat turut mempengaruhi perkembangan pada media massa. Salah satu jenis media massa yang mempunyai pengaruh besar terhadap khalayak khususnya para remaja adalah media audio visual baik televisi, film maupun video game. Penelitian yang dilakukan oleh Milla menyatakan bahwa salah satu media massa yang diyakini memiliki pengaruh yang kuat pada khalayak adalah media audio visual. Kekuatan pengaruh media audio visual disebabkan media jenis ini tidak hanya mampu mengoptimalkan pesan melalui pendengaran, melainkan juga penglihatan dan gerakan sekaligus, dimana pesan bergerak 
memiliki daya tarik lebih dibandingkan pesan statis.

Televisi, film maupun video game dari hari ke hari mengalami banyak kemajuan dan perubahan baik dari segi fungsinya hingga pergeseran ketertarikan pada jenis konten isi yang ditayangkan yang mengarah pada unsur kekerasan. Masyarakat khususnya para remaja terlena akan manisnya unsur kekerasan yang dikemas sedemikian rupa sehingga dapat menumpulkan tingkat toleransi terhadap tindakan kekerasan. Paparan tindakan kekerasan yang ditayangkan pada program acara di televisi mampu membuat para penontonnya kehilangan tingkat toleransi terhadap kekerasan. Akan tetapi, media audio visual seperti video game mempunyai dampak yang lebih besar dibandingkan dengan media televisi dalam mempengaruhi tingkat agresivitas remaja. Video game mampu membawa para pemainnya masuk ke dalam suasana yang sesuai dengan konten atau jenis permainannya dimana para pemain diwakili oleh avatar dalam permainan tersebut.

Perkembangan teknologi begitu pesat mempengaruhi bentuk dan jenis permainan mulai dari playstation, nine tendo, game console, $i$ pad serta game online dan sebagainya dengan konten permainan yang berbeda jauh dari permainan tradisional. Perkembangan teknologi dalam bidang permainan memuat konten permainan yang banyak mengandung unsur kekerasan contohnya game online point blank yang mengarahkan para pemain untuk terus melakukan tindakan kekerasan dalam video game tersebut demi mencapai kemenangan. Sebuah penelitian yang dilakukan oleh $\mathrm{Dr}$ Vincent Mathews, profesor radiologi di Universitas Indiana Fakultas Kesehatan dan tim risetnya telah membuktikan bahwa otak anakanak dan remaja dapat berubah singkat sebagai hasil dari bermain video game kekerasan. Penelitian ini menunjukkan bahwa setelah bermain video game bertema kekerasan selama 30 menit akan menyebabkan adanya peningkatan aktivitas bagian otak anak-anak dan remaja yang berhubungan dengan reaksi emosional manusia, yaitu amigdala ${ }^{1}$. Selaras dengan hal tersebut,

\footnotetext{
1 Amigdala adalah sekelompok saraf bentuknya seperti kacang almond, merupakan bagian otak yang berperan dalam melakukan pengolahan dan ingatan terhadap reaksi
}

penelitian yang dilakukan oleh Kurniawati (2010) menunjukkan hal yang sama bahwa diperoleh hasil analisis data terdapat hubungan positif sangat signifikan antara bermain game online dan perilaku agresi pada remaja. Semakin tinggi skor bermain game online, maka semakin tinggi pula skor perilaku agresi pada remaja. Sebaliknya, semakin rendah skor bermain game online maka semakin rendah pula skor perilaku agresi remaja. Oleh sebab itu, media audio visual khususnya video game berunsur kekerasan mempunyai peranan penting dalam membentuk dan meningkatkan tingkat agresivitas remaja.

Berdasarkan latar belakang yang telah diuraikan diatas, maka masalah penelitian yang dikemukakan antara lain:

1. Bagaimana video game berunsur kekerasan berpengaruh terhadap perilaku agresi remaja?

2. Bagaimana faktor personal turut mempengaruhi perilaku remaja dalam bermain video game berunsur kekerasan?

3. Bagaimana faktor situasional turut mempengaruhi perilaku remaja dalam bermain video game berunsur kekerasan?

\section{PENDEKATAN TEORITIS}

\section{Perilaku Agresi}

Myers (2012) mendefinisikan agresi (aggression) sebagai perilaku fisik atau verbal yang bertujuan untuk menyakiti orang lain. Perilaku yang termasuk dalam definisi agresi ini, yaitu menendang dan menampar, mengancam dan menghina, bahkan bergunjing (gosip) atau menyindir. Perilaku lain yang termasuk batasan definisi agresi, yaitu menghancurkan barang, berbohong, dan perilaku lainnya yang memiliki tujuan untuk menyakiti. Menurut Nashori (2008) mengacu pada Buss, ada delapan bentuk perilaku agresif, yaitu 1) perilaku agresif fisik aktif yang dilakukan secara langsung, 2) perilaku agresif fisik aktif yang dilakukan secara tidak langsung, 3) perilaku agresif fisik pasif yang dilakukan secara langsung, 4) perilaku agresif fisik pasif yang dilakukan secara tidak langsung, 5) perilaku agresif verbal aktif yang dilakukan secara langsung, 6) perilaku agresif verbal aktif yang dilakukan secara tidak langsung, 7)

emosi. Disaat kita mendapatkan/menerima perbuatan/respon dari orang lain maka Amigdala ini berperan untuk merespon/mengolah emosi kita. 
perilaku agresif verbal pasif yang dilakukan secara tidak langsung, dan 8) perilaku agresif verbal pasif yang dilakukan secara langsung. Mengacu pada kedelapan bentuk perilaku agresi diatas maka bentuk perilaku agresi yang dilihat dalam penelitian ini adalah perilaku agresi verbal aktif yang dilakukan secara langsung, perilaku agresi verbal aktif yang dilakukan secara tidak langsung, perilaku agresi fisik aktif secara langsung, dan perilaku agresi fisik aktif yang dilakukan secara tidak langsung.

Menurut Myers (2012) pengaruh media yang dapat mempengaruhi perilaku agresi seseorang adalah televisi dan video game. Televisi meresap dalam kehidupan sehari-hari jutaan orang dan menayangkan kekerasan. Hasil penelitian korelasi dan eksperimental sepakat pada suatu kesimpulan bahwa keterpaparan terhadap kekerasan di televisi memiliki hubungan dengan perilaku agresi. Akan tetapi, dengan memainkan video game yang berisi kekerasan secara berulang-ulang dapat meningkatkan pikiran, perasaan, dan perilaku agresi, bahkan lebih rentan dibandingkan dengan menonton televisi atau film karena memainkan video games melibatkan partisipan secara aktif dibandingkan media lainnya. Penelitian lain yang dilakukan oleh Kurniawati (2010) membuktikan bahwa terdapat hubungan positif sangat signifikan antara bermain game online dan perilaku agresi pada remaja.

\section{Remaja}

Menurut Dariyo (2004), remaja (adolescence) adalah masa transisi atau peralihan dari masa kanak-kanak menuju masa dewasa yang ditandai dengan adanya perubahan aspek fisik, psikis, dan psikososial. Menurut Nurihsan dan Agustin (2011) para ahli cenderung mengadakan pembagian lagi ke dalam masa remaja awal awal (early adolescent, puberty) dan remaja akhir (late adolescent) yang mempunyai rentangan waktu antara 11-13 sampai 14-15 tahun dan 1416 sampai 18-20 tahun. Selama masa transisi atau peralihan dari masa kanak-kanak menuju masa dewasa pada diri remaja mengalami beberapa perubahan, menurut Kurniawati (2010) pada diri remaja terjadi perubahan fisik, psikis, seksual, kognitif dan sosial yang dapat menyebabkan meningkatnya ketegangan emosi, suara hati yang menjadi berubah-ubah, mudah marah, kesal tidak menentu, menolak aturan yang ada serta menunjukkan sikap yang antagonis.

\section{Perilaku Remaja Menggunakan Video game Berunsur Kekerasan}

Perilaku adalah kegiatan yang dilakukan oleh individu untuk mencapai tujuan tertentu. Berkaitan dengan remaja dan agresi maka dalam hal ini yang akan dibahas adalah perilaku remaja menggunakan media audio visual untuk menonton atau bermain video game berunsur kekerasan. Menurut Malahayati (2012), video game merupakan jenis permainan berbasis teknologi komputer yang menyediakan tantangan bagi koordinasi mata, tangan atau kemampuan mental seseorang dengan tujuan untuk menghibur penggunanya, dimana dalam penggunaannya dikontrol oleh perangkat lunak dan dimainkan pada video atau layar televisi. Perilaku bermain video game berunsur kekerasan adalah kegiatan bermain jenis permainan yang mengandung unsur kekerasan dengan menggunakan teknologi komputer yang bertujuan untuk menghibur penggunanya.

Penelitian yang dilakukan oleh Widyastuti (1996) mengukur perilaku menonton televisi melalui frekuensi menonton, program siaran yang ditonton, lamanya menonton, dan jenis film yang ditonton. Selaras dengan hal tersebut, Nando (2011) mengukur perilaku menonton televisi berunsur kekerasan melalui intensitas menonton film kekerasan, jenis film kekerasan yang ditonton, media menonton film, dan akses terhadap film. Seperti halnya Kurniawati (2010), mengukur perilaku bermain video game berunsur kekerasan melalui frekuensi bermain, lama waktu bermain, perhatian penuh, dan emosional dari responden. Selanjutnya, Gentilea et al. (2004) melakukan pengukuran perilaku bermain video game berunsur kekerasan melalui jenis video game favorit remaja, tingkat kekerasan permainan, banyaknya permainan kekerasan yang dimiliki, dan jumlah waktu yang dihabiskan.

Berdasarkan beberapa penelitian yang telah dilakukan maka dapat disimpulkan bahwa perilaku remaja dalam bermain video game berunsur kekerasan dapat diamati dengan mengukur frekuensi bermain, lama bermain, 
jenis yang dimainkan, media yang digunakan, dan tingkat kekerasan dalam video game. Akan tetapi, untuk mencapai pada perilaku tertentu dalam bermain video game berunsur kekerasan terdapat faktor lain yang mempengaruhinya yaitu faktor personal dan faktor situasional. Faktor personal adalah jenis kelamin, dan usia serta faktor situasional yang relevan dengan pengaruh media terhadap perilaku agresi remaja adalah faktor pembatas yang diberikan orang tua dalam menggunakan video game berunsur kekerasan, tingkat pengetahuan, dan pengaruh ajakan teman sebaya.

\section{Pengaruh Media Video game Berunsur Kekerasan Terhadap Perilaku Agresi Remaja}

Media massa yang diyakini memiliki pengaruh yang kuat pada khalayak adalah media audio visual (Milla [tahun tidak diketahui]). Menurut Milla [tahun tidak diketahui], kekuatan pengaruh media audio visual disebabkan media jenis ini tidak hanya mampu mengoptimalkan pesan melalui pendengaran, melainkan juga penglihatan dan gerakan sekaligus, dimana pesan bergerak memiliki daya tarik lebih dibandingkan pesan statis. Media video game merupakan bagian dari media audio visual yang memiliki kontribusi yang cukup kuat dalam merangsang timbulnya perilaku agresi. Beberapa penelitian menunjukkan bahwa pengaruh video game lebih besar dari pada dampak kekerasan yang ditayangkan di televisi. Hal ini selaras dengan hasil penelitian oleh Susan Persky dan James Blascovich (2005) bahwa "games virtual-reality memberikan permainan yang lebih nyata, lebih melibatkan, dan dampak yang lebih banyak" (Persky dan Blascovich 2005 dalam Myers 2012).

Di samping itu, penelitian yang dilakukan oleh Zulkifli (2013) menunjukkan bahwa ada hubungan antara bermain game online dengan tindakan kekerasan. Selaras dengan hal tersebut, Gentilea et al. (2004) mengungkapkan bahwa paparan konten video game berunsur kekerasan dan jumlah bermain video game berpengaruh pada sifat permusuhan remaja, frekuensi mereka terlibat dalam argumen guru, terlibat atau tidak dalam perkelahian dan negatif terkait nilai sekolah. Kekerasan dalam media juga dapat menyebabkan menumpulnya sensitivitas dan perasaan seseorang terhadap tindakan kekerasan atau disebut juga dengan teori desensitisasi. Menurut Vivian (2008) mengungkapkan bahwa teori desensitisasi ini menyatakan bahwa bukan hanya individu yang menjadi makin kasar akibat kekerasan di media tetapi juga toleransi masyarakat terhadap tindak kekerasan semakin meningkat.

\section{KERANGKA PENELITIAN}

Video game merupakan media audio visual yang dapat berpengaruh terhadap perilaku remaja. Salah satu dugaan dampak negatif dari bermain video game berunsur kekerasan adalah terjadinya perubahan perilaku agresi pada remaja. Bentuk perilaku agresi tersebut dalam penelitian ini dilihat dari ekspresi ketika marah, reaksi pada orang yang berperilaku agresi, tujuan berperilaku agresi dan perasaan yang muncul setelah berperilaku agresi. Perilaku agresi ini dipengaruhi oleh perilaku bermain video game yaitu frekuensi bermain, lama bermain, jenis video game kekerasan yang dimainkan, media bermain video game, dan tingkat kekerasan video game. Video game tidak langsung mempengaruhi perilaku pemain, diduga perubahan perilaku remaja menjadi agresif dikarenakan bermain video game berulangkali dengan frekuensi bermain dan lama bermain dalam jangka waktu yang lama, maka dari itu frekuensi bermain dan lama bermain berpengaruh pada perilaku agresi remaja.

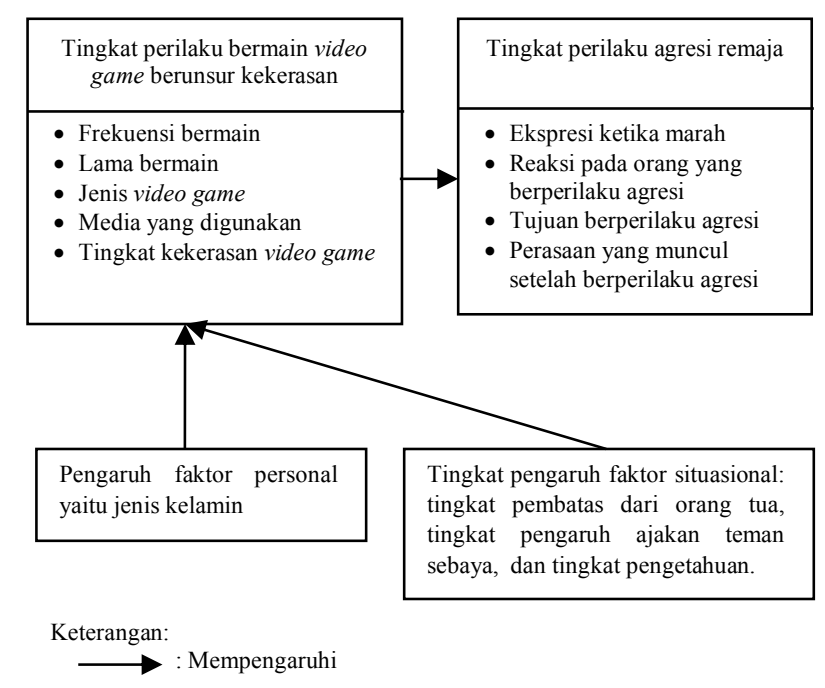

Gambar 1 Kerangka pemikiran

Akan tetapi, bermain video game saja tidak akan langsung membuat seseorang menjadi agresif 
ada faktor lain yang turut terlibat dalam proses terjadinya perilaku agresi remaja. Faktor personal pun mempengaruhi perubahan perilaku remaja. Faktor personal yang dimaksud adalah jenis kelamin. Selain itu, faktor situsasional pun dapat mempengaruhi dalam perubahan perilaku. Faktor situasional yang dibahas dalam penelitian ini adalah faktor pembatas dari orang tua dalam bermain video game berunsur kekerasan, pengaruh ajakan teman sebaya, dan pengetahuan.

\section{Hipotesis Penelitian}

Berdasarkan kerangka pemikiran tersebut, maka hipotesis dalam penelitian ini sebagai berikut:

1. Terdapat perbedaan pengaruh tingkat perilaku bermain video game berunsur kekerasan antara jenis kelamin perempuan dan jenis kelamin laki-laki.

2. Terdapat perbedaan pengaruh tingkat perilaku bermain video game berunsur kekerasan antara tingkat situasional sangat rendah, rendah, tinggi dan sangat tinggi yang diperoleh dari perhitungan tingkat pembatas dari orang tua, tingkat ajakan teman sebaya, dan tingkat pengetahuan.

3. Terdapat perbedaan pengaruh tingkat perilaku agresi remaja antara tingkat perilaku bermain video game berunsur kekerasan intensitas sangat rendah, intensitas rendah, intensitas tinggi, dan intensitas sangat tinggi.

\section{PENDEKATAN LAPANG}

\section{Lokasi dan Waktu Penelitian}

Penelitian ini dilakukan di Sekolah Menengah Kejuruan (SMK) "X", Jalan Raya Warung Borong, Kecamatan Ciampea, Kabupaten Bogor. Pemilihan lokasi penelitian didasarkan pada latar belakang sekolah yang sesuai dengan karakteristik responden dalam penelitian ini. Para siswa SMK "X" terdiri atas usia remaja awal dan remaja akhir serta siswa-siswi SMK " $X$ " pernah terlibat tawuran. Waktu penelitian dilaksanakan pada bulan Juni 2014 sampai Januari 2015 dimulai dari penyusunan proposal penelitian hingga perbaikan laporan penelitian. Waktu pengambilan data disesuaikan dengan jadwal kegiatan yang ada di SMK "X".

\section{Teknik Pengumpulan Data}

Penelitian ini menggunakan metode kuantitatif dengan cara menyebar kuesioner kepada para siswa SMK "X" untuk mengetahui perilaku bermain video game dan perilaku agresi remaja. Pengumpulan data dilakukan menggunakan metode cluster random sampling. Pengumpulan data menggunakan teknik cluster random sampling dikarenakan sampling frame atau kerangka sampel dalam hal ini adalah daftar semua siswa SMK " $X$ " telah dimiliki namun sulit untuk mengidentifikasi siswa yang masuk dalam karakteristik penelitian yaitu siswa yang sebulan terakhir bermain video game. Terdapat lima puluh enam kelas dengan jumlah keseluruhan yaitu 2.572 siswa.

Satu kelas dijadikan satu cluster karena dianggap memiliki tingkat keragaman yang relatif sama atau homogen antar kelas, namun memiliki tingkat keragaman yang tinggi (heterogen) dalam satu cluster itu sendiri. Cluster random sampling yang dilakukan dengan cara mengambil sampel acak dua kelas atau dua cluster pada setiap tingkatan kelas yakni dua kelas di kelas 1, dua kelas di kelas 2, dan dua kelas di kelas 3. Lalu, peneliti melakukan pengambilan sampel berdasarkan usia, jenis kelamin, kelas dan penggunaan video game sebulan terakhir. Jika dari hasil pencarian sampel tersebut belum mencapai sebanyak 30 sampel, langkah selanjutnya melakukan pendataan kedua ke kelas terdekat dari kelas yang sebelumnya. Jika dari pendataan sampel yang pertama peneliti telah mendapatkan sampel sebanyak 30 yang terdiri atas 15 siswa laki-laki dan 15 siswa perempuan yang telah bermain video game sebulan terakhir, peneliti dapat langsung melanjutkan penelitian dengan menggunakan kuesioner. Responden dalam penelitian ini berjumlah 90 siswa. Dalam penelitian ini jenis data yang dipergunakan adalah jenis data primer dan data sekunder. Data primer diperoleh melalui kuesioner dan berdasarkan pengamatan perilaku para responden. Data sekunder didapat melalui studi literatur.

\section{Teknik Pengolahan dan Analisis Data}

Berdasarkan hipotesis yang telah disampaikan sebelumnya, maka pengolahan dan analisis data merujuk pada hipotesis tersebut. Hipotesis pertama menggunakan uji Mann-Whitney dan dilihat apakah kesimpulan yang dihasilkan adalah terima hipotesis atau tidak. Terima hipotesis terjadi jika nilai p-value yang 
dihasilkan dari uji ini kurang dari taraf nyata yang digunakan yaitu 5\%. Terima hipotesis berarti cukup bukti untuk menyatakan terdapat perbedaan tingkat perilaku bermain video game berunsur kekerasan antara jenis kelamin perempuan dan laki-laki pada taraf nyata $5 \%$.

Hipotesis kedua dan ketiga menggunakan uji Kruskal-Wallis, prosedur ini mempunyai tujuan yang sama dengan ANOVA, yaitu melihat pengaruh beberapa peubah (lebih dari dua peubah) terhadap peubah responnya. Akan tetapi ANOVA menyaratkan adanya pemenuhan asumsi data yang berdistribusi normal serta skala pengukuran data minimal berskala interval, sedangkan uji Kruskal-Wallis yang merupakan uji non-paramterik tidak terikat pada asumsi tersebut, skala pengukuran minimal pada uji ini dapat berupa skala ordinal (Daniel 1990). Kriteria pengambilan kesimpulan ini dapat dilihat dari nilai $\mathrm{p}$-value yang kurang dari taraf nyata 5\% merupakan kriteria terima hipotesis yang berarti setidaknya ada satu kelompok intensitas yang signifikan berpengaruh terhadap respon, atau dengan kata lain, keempat kelompok intensitas bermain (sangat rendah, rendah, tinggi, dan sangat tinggi) secara bersamaan signifikan berpengaruh terhadap data respon, yaitu tingkat perilaku agresi remaja.

Pengolahan data dilakukan melalui beberapa langkah, yaitu editing kuesioner, pengkodean data, pemindahan data ke lembar penyimpanan data (Microsoft Excel). Selanjutnya, analisis data menggunakan perangkat lunak statistik untuk melakukan uji Mann-Whitney dan uji KruskalWallis.

\section{HASIL DAN PEMBAHASAN}

\section{Kondisi Personal dan Situasional Responden SMK "X"}

\section{Kondisi Personal}

Responden dalam penelitian ini berjumlah 90 siswa yang terdiri atas 45 siswa laki-laki dan 45 siswa perempuan yang diperoleh dari 15 siswa laki-laki dan 15 siswa perempuan pada setiap tingkatan kelas yaitu kelas X, XI dan XII. Responden siswa perempuan lebih banyak diusia remaja awal (13-16 tahun) dengan persentase $58.6 \%$ dari 58 responden yang tergolong kategori usia remaja awal (13-16 tahun), sedangkan untuk responden siswa laki-laki lebih banyak diusia remaja akhir (17-21 tahun) dengan persentase mencapai $65.6 \%$ dari 32 responden yang berusia remaja akhir (17-21 tahun).

\section{Kondisi Situasional}

Kondisi situasional dipengaruhi oleh faktorfaktor yang berasal dari luar diri individu yang mempengaruhi perilaku individu tersebut, dalam hal ini adalah tingkat pembatasan dari orang tua dalam bermain video game berunsur kekerasan, tingkat pengaruh ajakan teman sebaya untuk bermain video game, dan tingkat pengetahuan tentang dampak bermain video game berunsur kekerasan secara berlebihan. Tingkat pembatasan dari orang tua, tingkat pengaruh ajakan teman sebaya, dan tingkat pengetahuan responden dapat dilihat pada Tabel 1 .

Tabel 1 Jumlah dan persentase responden berdasarkan tingkat situasional

\begin{tabular}{lcccccc}
\hline & \multicolumn{5}{c}{ Faktor situasional } \\
\cline { 2 - 7 } $\begin{array}{c}\text { Tingkat } \\
\text { situasional }\end{array}$ & $\begin{array}{c}\text { Tingkat } \\
\text { pembatasan } \\
\text { dari orang } \\
\text { tua }\end{array}$ & $\begin{array}{c}\text { Tingkat } \\
\text { pengaruh } \\
\text { ajakan } \\
\text { teman } \\
\text { sebaya }\end{array}$ & $\begin{array}{c}\text { Tingkat } \\
\text { pengetahuan }\end{array}$ \\
\cline { 2 - 7 } & $\mathrm{n}$ & $\%$ & $\mathrm{n}$ & $\%$ & $\mathrm{n}$ & $\%$ \\
\hline $\begin{array}{l}\text { Sangat } \\
\text { rendah }\end{array}$ & 11 & 12 & 40 & 44 & 3 & 3 \\
$\begin{array}{l}\text { Tinggi } \\
\text { Sangat } \\
\text { tinggi }\end{array}$ & 33 & 37 & 33 & 37 & 50 & 56 \\
\hline Jumlah & 90 & 10 & 16 & 18 & 27 & 30 \\
\hline
\end{tabular}

Tabel 1 menunjukkan bahwa pada umumnya tingkat pembatasan dari orang tua dalam bermain video game berunsur kekerasan tergolong tinggi dengan persentase $49 \%$ responden. Tingkat pengaruh ajakan teman sebaya mayoritas tergolong sangat rendah dengan persentase mencapai $40 \%$ dari 90 responden. Tingkat pengetahuan responden mayoritas rendah dengan persentase sebesar $56 \%$ dari 90 responden. Oleh sebab itu, secara keseluruhan tingkat situasional responden tergolong rendah seperti pada Gambar 2.

Gambar 2 menunjukkan bahwa mayoritas tingkat situasional responden untuk berperilaku bermain video game berunsur kekerasan tergolong pada kategori rendah dengan jumlah responden sebanyak 57 siswa dari 90 responden. Hal ini menunjukkan responden cenderung di batasi 
dalam bermain video game berunsur kekerasan, ajakan teman yang cenderung tidak terlalu sering, dan pengetahuan tentang dampak bermain video game berunsur kekerasan yang cukup baik. Di samping itu, pada gambar 2 juga menunjukkan bahwa terdapat 25 dari 90 responden tergolong pada tingkat situasional tinggi, hal ini berarti bahwa hanya 25 responden saja yang cenderung diberi kebebasan dalam bermain video game oleh orang tuanya, cenderung sering menerima ajakan teman sebaya untuk bermain video game berunsur kekerasan, dan pengetahuan tentang dampak bermain video game berunsur kekerasan yang cenderung kurang.

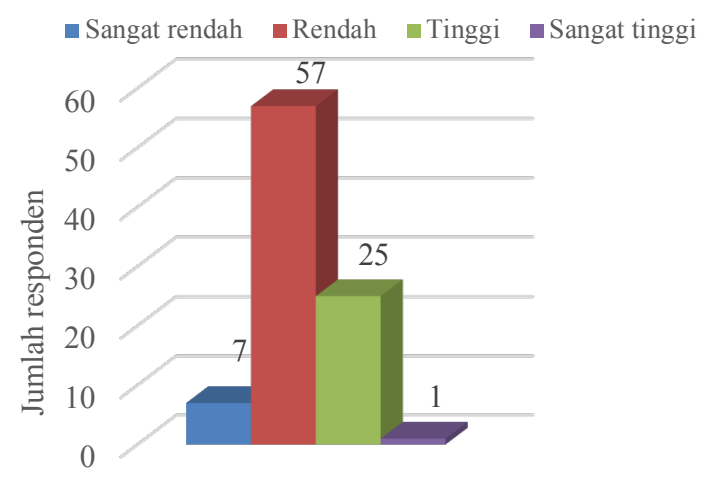

Tingkat situasional

Gambar 2 Jumlah responden berdasarkan tingkat situasional dalam bermain video game berunsur kekerasan

Berbeda dengan tingkat situasional sangat tinggi hanya terjadi pada 1 dari 90 responden yang berarti bahwa hanya 1 responden saja yang diberikan kebebasan dalam bermain video game oleh orang tuanya, lebih seringnya menerima ajakan teman untuk bermain video game berunsur kekerasan, dan pengetahuan tentang dampak bermain video game berunsur kekerasan yang sangat kurang. Selanjutanya sebanyak 7 dari 90 responden menunjukkan tingkat situasional yang sangat rendah hal ini berarti bahwa sebanyak 7 responden cenderung lebih banyak dibatasi dalam bermain video game oleh orang tua, cenderung tidak menerima ajakan teman untuk bermain video game dan cenderung memiliki tingkat pengetahuan tentang dampak bermain video game berunsur kekerasan yang bagus.

\section{Perilaku Bermain Video Game Berunsur Kekerasan}

Perilaku bermain video game berunsur kekerasan terdiri atas frekuensi bermain, lama bermain, jenis video game, media yang digunakan, dan tingkat kekerasan video game.

\section{Frekuensi bermain}

Frekuensi bermain video game adalah seberapa sering seseorang bermain video game berunsur kekerasan dalam perminggu.

Tabel 2 Jumlah dan persentase frekuensi bermain video game dalam per minggu berdasarkan jenis kelamin

\begin{tabular}{lllllll}
\hline \multirow{2}{*}{ Frekuensi bermain } & \multicolumn{2}{c}{ Laki-laki } & \multicolumn{2}{c}{ Perempuan } & \multicolumn{2}{c}{ Jumlah } \\
\cline { 2 - 7 } & \multicolumn{2}{c}{$\%$} & $\mathrm{n}$ & $\%$ & $\mathrm{~N}$ & $\%$ \\
\hline Sangat rendah & 21 & 47 & 29 & 64 & 50 & 56 \\
Rendah & 10 & 22 & 9 & 20 & 19 & 21 \\
Tinggi & 4 & 9 & 0 & 0 & 4 & 4 \\
Sangat tinggi & 10 & 22 & 7 & 16 & 17 & 19 \\
\hline Jumlah & 45 & 100 & 45 & 100 & 90 & 100 \\
\hline
\end{tabular}

Berdasarkan pada Tabel 2 diperoleh bahwa frekuensi bermain video game berunsur kekerasan pada umumnya adalah sangat rendah sebesar $56 \%$. Frekuensi sangat rendah lebih banyak terjadi pada responden perempuan sebesar $64 \%$ dibandingkan dengan responden laki-laki sebesar $47 \%$ sedangkan frekuensi rendah lebih banyak terjadi pada responden laki-laki sebesar 22\% dibandingkan dengan responden perempuan sebesar $20 \%$. Akan tetapi, pada frekuensi tinggi dan sangat tinggi terjadi lebih banyak pada responden laki-laki sebesar $9 \%$ dan $22 \%$ dibandingkan dengan responden perempuan pada frekuensi tinggi tidak dan sebesar 16\% untuk frekuensi sangat tinggi.

\section{Lama bermain}

Lama bermain video game adalah banyaknya waktu yang digunakan seseorang untuk bermain video game, semakin banyak waktu yang digunakan dalam bermain video game maka menunjukkan semakin lama seseorang itu bermain video game.

Berdasarkan pada Tabel 3 diperoleh bahwa lama bermain video game berunsur kekerasan pada hari Senin sampai Sabtu pada umumnya tergolong sangat rendah. Lama bermain video 
game berunsur kekerasan yang tergolong sangat rendah lebih banyak terjadi pada responden perempuan sebesar $96 \%$ dibandingkan dengan responden laki-laki sebesar $89 \%$.

Tabel 3 Jumlah dan persentase responden berdasarkan jenis kelamin dan lama bermain video game berunsur kekerasan pada hari Senin sampai Sabtu

\begin{tabular}{lrrrrrr}
\hline \multirow{2}{*}{$\begin{array}{c}\text { Lama bermain } \\
\text { video game }\end{array}$} & \multicolumn{2}{c}{ Laki-laki } & \multicolumn{2}{c}{ Perempuan } & \multicolumn{2}{c}{ Jumlah } \\
\cline { 2 - 7 } & \multicolumn{1}{c}{$\mathrm{n}$} & $\%$ & $\mathrm{n}$ & $\%$ & $\mathrm{~N}$ & $\%$ \\
\hline Sangat rendah & 40 & 89 & 43 & 96 & 83 & 92 \\
Rendah & 4 & 9 & 1 & 2 & 5 & 6 \\
Tinggi & 1 & 2 & 1 & 2 & 2 & 2 \\
Sangat tinggi & 0 & 0 & 0 & 0 & 0 & 0 \\
\hline Jumlah & 45 & 100 & 45 & 100 & 90 & 100 \\
\hline
\end{tabular}

Walau demikian, lama bermain video game berunsur kekerasan pada hari Senin sampai Sabtu yang tergolong rendah dan tinggi lebih banyak terjadi pada responden laki-laki sebesar $9 \%$ dan $2 \%$, sedangkan responden perempuan hanya mencapai $2 \%$ untuk kategori rendah dan tinggi. Lama bermain video game yang tergolong sangat tinggi baik responden laki-laki maupun perempuan tidak ada.

Tabel 4 Jumlah dan persentase responden berdasarkan jenis kelamin dan lama bermain video game berunsur kekerasan pada hari libur

\begin{tabular}{lcccccc}
\hline \multirow{2}{*}{$\begin{array}{c}\text { Lama bermain } \\
\text { video game }\end{array}$} & \multicolumn{2}{c}{ Laki-laki } & \multicolumn{2}{c}{ Perempuan } & \multicolumn{2}{c}{ Jumlah } \\
\cline { 2 - 7 } & $\mathrm{n}$ & $\%$ & $\mathrm{n}$ & $\%$ & $\mathrm{~N}$ & $\%$ \\
\hline Sangat rendah & 29 & 65 & 39 & 87 & 68 & 76 \\
Rendah & 11 & 24 & 5 & 11 & 16 & 18 \\
Tinggi & 5 & 11 & 0 & 0 & 5 & 5 \\
Sangat tinggi & 0 & 0 & 1 & 2 & 1 & 1 \\
\hline Jumlah & 45 & 100 & 45 & 100 & 90 & 100 \\
\hline
\end{tabular}

Selanjutnya, dari Tabel 4 diperoleh bahwa lama bermain video game berunsur kekerasan pada hari libur umumnya tergolong sangat rendah. Lama bermain video game berunsur kekerasan pada hari libur yang tergolong sangat rendah lebih banyak terjadi pada responden perempuan sebesar $87 \%$ sedangakan laki-laki sebesar $65 \%$. Walau demikian, lama bermain video game berunsur kekerasan pada hari libur yang tergolong rendah dan tinggi lebih banyak terjadi pada responden laki-laki sebesar $24 \%$ dan $11 \%$, sedangkan responden perempuan hanya mencapai 5\% tergolong rendah. Akan tetapi, untuk yang tergolong sangat tinggi hanya terjadi pada 1 responden perempuan. Secara keseluruhan, dari Tabel 5 dan Tabel 6 menunjukkan bahwa untuk lama bermain pada hari Senin sampai Sabtu ataupun pada hari libur, lama bermain video game berunsur kekerasan baik responden perempuan maupun laki-laki tergolong pada kategori sangat rendah.

\section{Jenis video game}

Jenis video game berunsur kekerasan adalah macam-macam jenis game yang dimainkan oleh responden yang berunsur kekerasan. Responden laki-laki dan perempuan cenderung lebih banyak memainkan jenis video game petualangan dengan jumlah responden sebanyak 58 dari 90 responden yang terdiri atas 36 responden laki-laki dan 22 responden perempuan. Pada umumnya, responden laki-laki lebih memilih jenis video game simulasi kendaraan sebanyak 37 responden, petualangan sebanyak 36 responden, pertarungan sebanyak 33 responden, dan tembak-tembakan sebanyak 31 responden, sedangkan responden perempuan lebih memilih jenis video game petualangan sebanyak 22 responden, tembaktembakan sebanyak 19 responden, pertarungan dan simulasi kendaraan sebanyak 16 responden. Frekuensi bermain dan lama bermain video game berunsur kekerasan baik responden laki-laki maupun perempuan tergolong sangat rendah, tetapi jenis video game yang dimainkan oleh para responden lebih banyak mengandung unsur kekerasan.

\section{Media yang digunakan}

Media bermain video game berunsur kekerasan adalah jenis alat yang digunakan untuk dapat bermain video game berunsur kekerasan. Pada umumnya, responden lebih banyak menggunakan handphone dan gagdet baik secara online maupun secara offline dalam mengakses video game berunsur kekerasan dengan jumlah responden sebanyak 76 dari 90 responden. Responden perempuan lebih banyak memilih menggunakan media handphone dan gadget untuk bermain video game berunsur kekerasan sebanyak 41 
responden dibandingkan dengan responden laki-laki sebanyak 35 responden. Handphone dan gagdet bukan merupakan barang mewah lagi karena harganya yang saat ini mudah terjangkau oleh semua kalangan. Kemudahan dibawa dan dipergunakan kapan saja baik secara online maupun offline untuk bermain video game berunsur kekerasan menjadikan alat ini diminati oleh para responden. Akan tetapi, sebanyak 38 responden laki-laki lebih memilih untuk menggunakan playstation di tempat-tempat penyewaan.

\section{Tingkat kekerasan video game}

Tingkat kekerasan video game adalah seberapa keras atau kejam permainan yang dimainkan oleh seseorang. Penilaian terhadap tingkat kekerasan video game ini merupakan penilaian menurut responden sendiri. Pada umumnya, dari 90 responden umumnya memberikan penilaian terhadap tingkat kekerasan jenis video game yang dimainkan tergolong pada permainan keras. Responden laki-laki cenderung lebih banyak setuju untuk memberikan penilaian yang tergolong keras pada jenis permainan petualangan sebanyak 28 responden dan sebanyak 25 responden pada jenis permainan pertarungan. Sebaliknya, hanya 18 responden perempuan yang setuju memberikan penilaian keras pada jenis video game simulasi kendaraan dan hanya 9 responden perempuan yang setuju memberikan penilaian keras pada jenis video game petualangan yang mereka mainkan.

Jadi, secara keseluruhan perilaku bermain video game berunsur kekerasan yang terdiri atas frekuensi bermain, lama bermain, jenis video game, media yang digunakan, dan tingkat kekerasan video game tergolong pada intensitas rendah (dapat dilihat pada Tabel 5).

Tabel 5 Jumlah dan persentase responden bermain video game berunsur kekerasan berdasarkan jenis kelamin

\begin{tabular}{lcccccc}
\hline $\begin{array}{c}\text { Perilaku bermain } \\
\text { video game } \\
\text { berunsur } \\
\text { kekerasan }\end{array}$ & $\mathrm{n}$ & $\%$ & $\mathrm{n}$ & $\%$ & $\mathrm{~N}$ & $\%$ \\
\cline { 2 - 7 } & 0 & 0 & 9 & 20 & 9 & 10 \\
\hline Sangat rendah & 24 & 53 & 31 & 69 & 55 & 61 \\
Rendah & 19 & 42 & 5 & 11 & 24 & 27 \\
Tinggi & 2 & 5 & 0 & 0 & 2 & 2 \\
\hline Sangat tinggi & 45 & 100 & 45 & 100 & 90 & 100 \\
\hline Jumlah & & & & & & \\
\hline
\end{tabular}

Tabel 5 memperlihatkan bahwa sebesar $61 \%$ responden memiliki intensitas bermain video game berunsur kekerasan yang tergolong rendah. Perilaku bermain video game berunsur kekerasan dengan intensitas rendah banyak terjadi pada responden perempuan $(69 \%)$ dibandingkan dengan responden laki-laki (53\%). Selanjutnya, intensitas bermain video game berunsur kekerasan yang tergolong sangat rendah hanya terjadi pada responden perempuan sebesar $20 \%$. Akan tetapi, perilaku bermain video game berunsur kekerasan dengan intensitas tinggi dan sangat tinggi lebih banyak terjadi pada responden laki-laki yaitu sebesar $42 \%$ dan sebesar 5\% dibandingkan dengan responden perempuan hanya terjadi pada intensitas tinggi sebesar $11 \%$.

\section{Perilaku Agresi Remaja}

Perilaku agresi remaja terdiri atas ekspresi ketika marah, reaksi pada orang yang berperilaku agresi, tujuan berperilaku agresi, dan perasaan yang muncul setelah berperilaku agresi.

\section{Ekspresi ketika marah}

Ekspresi ketika marah adalah tindakan seseorang dalam meluapkan emosinya. Pada umumnya, dari 90 responden lebih memilih untuk mengekspresikan marah dengan agresi verbal aktif secara langsung yaitu mengejek dan memaki-maki sebanyak 15 responden dan 14 responden. Responden laki-laki memiliki perilaku agresi lebih tinggi dibandingkan responden perempuan. Responden laki-laki cenderung mengekspresikan marah dengan cara agresi verbal aktif secara langsung yaitu mengejek sebanyak 12 responden dan agresi fisik aktif secara langsung yaitu menampar sebanyak 10 responden. Sebaliknya, responden perempuan cenderung memiliki perilaku agresi yang rendah seperti yang terlihat pada gambar diatas, yaitu hanya ada 6 responden yang mengekspresikan marah dengan cara agresi verbal aktif secara langsung yaitu memaki-maki dan 4 responden yang mengekspresikan marah dengan cara agresi fisik aktif secara tidak langsung yaitu membuat jebakan untuk mencelakakan orang lain. Selain itu, hanya ada responden laki-laki yang mengekspresikan marah dengan cara menendang sebanyak 7 
responden daripada responden perempuan yang tidak ada sama sekali mengekspresikan marah dengan menendang. Akan tetapi, hanya ada 1 responden perempuan yang menjawab mengontrol emosinya ketika marah dibandingkan responden laki-laki sebanyak 9 responden.

\section{Reaksi pada orang yang berperilaku agresi}

Reaksi perilaku agresi adalah respon seseorang terhadap orang lain yang berperilaku agresi kepadanya. Pada umumnya, dari 90 responden umumnya memilih untuk membalas menyerang terhadap seseorang yang berperilaku agresi terhadap dirinya sebanyak 37 responden. Selain itu, responden laki-laki cenderung lebih agresi daripada responden perempuan. Responden laki-laki sebanyak 24 orang dan responden perempuan sebanyak 13 orang lebih menyetujui untuk melakukan pembalasan terhadap lawan sebagai wujud dari reaksi pada orang yang berperilaku agresi. Di samping itu, baik responden lakilaki maupun responden perempuan hanya terdapat 9 responden saja yang akan menghindar ketika ada yang berperilaku agresi, sedangkan untuk reaksi membuatkan jebakan ketika ada yang berperilaku agresi lebih banyak terjadi pada responden lakilaki sebanyak 7 responden daripada responden perempuan yang hanya terjadi pada 2 responden.

\section{Tujuan berperilaku agresi}

Tujuan berperilaku agresi adalah alasan seseorang untuk berperilaku agresi. Pada umumnya, hanya sedikit responden yang memiliki perasaan agresi berdasarkan dari tujuan berperilaku agresi. Responden lakilaki dan perempuan yang memilih mempertahankan gengsi sebagai tujuan berperilaku agresi hanya mencapai 10 responden untuk laki-laki dan 5 responden untuk perempuan. Selanjutnya, sebanyak 9 responden laki-laki lebih memilih untuk memberi pelajaran terhadap lawan sebagai tujuan mereka melakukan perilaku agresi daripada responden perempuan yaitu hanya mencapai 2 responden. Di samping itu, hanya terdapat 3 responden laki-laki memilih memuaskan emosi sebagai tujuan dari berperilaku agresi, sedangkan pada responden perempuan hanya terjadi pada 1 responden.

4. Perasaan yang muncul setelah berperilaku agresi

Perasaan yang muncul setelah melakukan perilaku agresi adalah kesan yang dirasakan seseorang setelah melakukan tindakan agresi. Pada umumnya, perasaan kasihan muncul di beberapa responden baik laki-laki (11 responden) maupun perempuan (5 responden). Walau demikian, dari gambar 9 juga memperlihatkan bahwa beberapa responden laki-laki memiliki perasaan yang cenderung agresif daripada perempuan. Perasaan agresif yang cenderung dirasakan dari 90 responden setelah berperilaku agresif adalah tidak ada sebanyak 10 responden laki-laki dan 5 responden perempuan. Hal ini menunjukkan beberapa responden tergolong pada perilaku agresi yang disebabkan oleh meningkatnya toleransi terhadap kekerasan sehingga tidak ada perasaan apapun terhadap tindakan yang dilakukan meskipun salah. Di samping itu, perasaan senang lebih banyak terjadi pada responden perempuan sebanyak 8 responden daripada responden laki-laki hanya 6 responden. Akan tetapi, perasaan puas lebih banyak terjadi pada responden laki-laki yaitu sebanyak 8 responden daripada responden perempuan hanya terjadi pada 2 responden.

Jadi, secara keseluruhan perilaku agresi remaja di SMK "X" yang terdiri atas ekspresi ketika marah, reaksi pada orang yang berperilaku agresi, tujuan berperilaku agresi, dan perasaan yang muncul setelah berperilaku agresi umumnya tergolong pada tingkat perilaku agresi yang rendah (Tabel 6).

Tabel 6 Jumlah dan persentase responden berdasarkan perilaku agresi

\begin{tabular}{lcc}
\hline Perilaku agresi & $\begin{array}{c}\text { Jumlah } \\
(\mathrm{n})\end{array}$ & $\begin{array}{c}\text { Persentase } \\
(\%)\end{array}$ \\
\hline Sangat rendah & 33 & 37 \\
Rendah & 51 & 57 \\
Tinggi & 5 & 5 \\
Sangat tinggi & 1 & 1 \\
\hline Jumlah & 90 & 100 \\
\hline
\end{tabular}


Berdasarkan data diatas diperoleh bahwa perilaku agresi responden tergolong pada tingkat yang rendah, yaitu sebesar $57 \%$ dari 90 responden. Selanjutnya, untuk perilaku agresi sangat rendah mencapai $37 \%$ dari 90 responden. Akan tetapi, dari 90 responden tersebut ada yang memiliki perilaku agresi yang sangat tinggi sebesar $1 \%$ dan perilaku agresi tinggi sebesar $5 \%$.

\section{Analisis Perbedaan Pengaruh Tingkat Perilaku Bermain Video Game Berunsur Kekerasan antara Jenis Kelamin Perempuan dan Jenis Kelamin Laki-Laki}

Jenis kelamin turut memberikan kontribusi dalam perilaku bermain video game berunsur kekerasan dengan intensitas rendah, sangat rendah, tinggi, dan sangat tinggi. Perbedaan perilaku bermain video game berdasar pada jenis kelamin dapat dilihat pada tabulasi silang Tabel 7.

Tabel 7 Perilaku bermain video game berunsur kekerasan berdasarkan jenis kelamin

\begin{tabular}{lccc}
\hline \multirow{2}{*}{$\begin{array}{c}\text { Perilaku bermain } \\
\text { video game berunsur } \\
\text { kekerasan }\end{array}$} & \multicolumn{2}{c}{ Jenis kelamin } & \\
\cline { 2 - 3 } & $\begin{array}{c}\text { Laki- } \\
\text { laki }\end{array}$ & Perempuan & Jumlah \\
\hline Sangat rendah & 0 & 9 & 9 \\
Rendah & 24 & 31 & 55 \\
Tinggi & 19 & 5 & 24 \\
Sangat tinggi & 2 & 0 & 2 \\
\hline Jumlah & 45 & 45 & 90 \\
\hline
\end{tabular}

Tabel 7 memperlihatkan bahwa baik responden laki-laki maupun perempuan dalam hal bermain video game berunsur kekerasan tergolong dalam kategori rendah sebanyak 24 responden laki-laki dan sebanyak 31 responden perempuan tergolong pada perilaku bermain yang rendah. Tabel 9 juga menunjukkan bahwa responden laki-laki memiliki intensitas bermain video game berunsur kekerasan yang cenderung lebih tinggi daripada responden perempuan. Intensitas bermain video game berunsur kekerasan yang tergolong sangat rendah hanya terjadi pada responden perempuan saja (sebanyak 9 responden). Sebaliknya, hanya ada responden laki-laki yang memiliki intensitas bermain video game berunsur kekerasan yang tergolong sangat tinggi yaitu sebanyak 2 responden. Di samping itu, intensitas tinggi lebih banyak terjadi pada responden laki-laki sebanyak 19 responden daripada responden perempuan sebanyak 5 responden. Pada umumnya, responden laki-laki dengan responden perempuan memiliki perbedaan intensitas dalam berperilaku bermain video game berunsur kekerasan.

Selanjutnya, untuk melihat adanya perbedaan pengaruh yang signifikan maka dilakukan analisis menggunakan uji Mann-Whitney. Terima hipotesis terjadi jika nilai probabilitas (p-value) yang dihasilkan dari uji ini kurang dari taraf nyata yang digunakan yaitu $5 \%$. Terima hipotesis berarti cukup bukti untuk menyatakan bahwa terdapat perbedaan tingkat perilaku bermain video game berunsur kekerasan antara jenis kelamin perempuan dan jenis kelamin laki-laki pada taraf nyata $5 \%$.

Tabel 8 Hasil uji statistik perbedaan tingkat perilaku bermain video game berunsur kekerasan antara jenis kelamin laki-laki dan perempuan

\begin{tabular}{cc}
\hline Uji statistik & $\begin{array}{c}\text { Perilaku bermain video } \\
\text { game berunsur kekerasan }\end{array}$ \\
\cline { 2 - 2 } Mann-Whitney $U$ & 464.500 \\
p-value & 0.000 \\
\hline Sumber: hasil uji Mann-Whitney &
\end{tabular}

Berdasarkan hasil uji Mann-Whitney diperoleh nilai probabilitas ( $\mathrm{p}$-value) sebesar 0.000 yang menunjukkan bahwa nilai p-value lebih kecil daripada taraf nyata yang digunakan yaitu 0.05 atau 5\%. Hal ini berarti bahwa terdapat perbedaan tingkat perilaku bermain video game berunsur kekerasan antara jenis kelamin perempuan dan jenis kelamin laki-laki pada taraf nyata 5\%. Ringkasnya, terdapat perbedaan pengaruh jenis kelamin terhadap perilaku bermain video game berunsur kekerasan.

\section{Analisis Perbedaan Pengaruh Tingkat Perilaku Bermain Video Game Berunsur Kekerasan berdasarkan Faktor Situasional}

Perilaku seseorang dalam bermain video game tidak hanya dipengaruhi oleh keadaan personal seseorang namun juga dipengaruhi oleh keadaan situasional. Keadaan situasional dipengaruhi oleh faktor-faktor yang berasal dari luar diri individu yang mempengaruhi perilaku individu tersebut, dalam hal ini adalah tingkat pembatasan dari orang tua dalam bermain video game berunsur kekerasan, tingkat pengaruh ajakan teman sebaya untuk bermain video game, dan tingkat 
pengetahuan tentang dampak bermain video game berunsur kekerasan secara berlebihan.

Tabel 9 Perilaku bermain video game berdasarkan keadaan situasional

\begin{tabular}{ccccc}
\hline \multirow{2}{*}{$\begin{array}{c}\text { Perilaku } \\
\text { bermain } \\
\text { video game } \\
\text { berunsur } \\
\text { kekerasan }\end{array}$} & $\begin{array}{c}\text { Sangat } \\
\text { rendah }\end{array}$ & Rendah & Tinggi & $\begin{array}{c}\text { Sangat } \\
\text { tinggi }\end{array}$ \\
\hline $\begin{array}{c}\text { Sangat } \\
\text { rendah }\end{array}$ & 1 & 8 & 0 & 0 \\
$\begin{array}{c}\text { Rendah } \\
\text { Tinggi }\end{array}$ & 6 & 38 & 11 & 0 \\
$\begin{array}{c}\text { Sangat } \\
\text { tinggi }\end{array}$ & 0 & 11 & 13 & 0 \\
\hline Jumlah & 7 & 0 & 1 & 1 \\
\hline
\end{tabular}

Tabel 9 memperlihatkan perbedaan intensitas perilaku bermain video game berunsur kekerasan yang disebabkan oleh perbedaan situasional. Berdasarkan pada tabel tersebut didapat bahwa sebanyak 57 responden dengan tingkat situasional yang rendah, 38 responden menunjukkan perilaku bermain video game yang rendah, 8 responden menunjukkan perilaku bermain video game yang sangat rendah, 11 responden menunjukkan perilaku bermain video game yang tinggi dan tidak ada responden yang menunjukkan perilaku bermain video game dengan intensitas tinggi. Selanjutnya dari 7 responden dengan tingkat situasional yang sangat rendah hanya 1 responden yang tergolong pada perilaku bermain video game yang sangat rendah dan 6 responden yang tergolong pada intensitas rendah dalam bermain video game. Berikutnya, untuk tingkat situasional tinggi, dari 25 responden dengan tingkat situasional tinggi terdapat 13 responden dengan intensitas perilaku bermain video game yang tergolong tinggi, 1 responden dengan intensitas bermain video game yang tinggi dan 11 responden dengan intensitas bermain video game yang rendah. Akan tetapi, hanya 1 responden dengan tingkat situasional yang tinggi memiliki intensitas bermain video game yang sangat tinggi.

Berdasakan Tabel 9 dapat disimpulkan bahwa tingkat situasional yang tinggi menimbulkan perilaku bermain video game yang tinggi dan sebaliknya, tingkat situasional yang rendah menimbulkan perilaku bermain video game yang rendah juga. Akan tetapi, beberapa responden menunjukkan hal yang berbeda, terdapat 11 responden dengan tingkat situasional yang tinggi menunjukkan perilaku bermain video game berunsur kekerasan yang rendah. Hal ini disebabkan oleh kurangnya motivasi dalam diri responden untuk bermain video game berunsur kekerasan walaupun tingkat pembatasan dari orang tua, dan tingkat ajakan teman sebaya mendukung untuk bermain video game berunsur umkakkerasan. Sebaliknya, terdapat 11 responden dengan tingkat situasional yang rendah menunjukkan perilaku bermain video game 9berunsur kekerasan yang tinggi karena kondisi 5 sekolah yang memberikan siswa kelonggaran ${ }^{24}$ untuk menggunakan smartphone atau handphone 2dan gagdet di lingkungan sekolah, sehingga ${ }_{9}{ }^{\text {esponden }}$ yang memiliki motivasi dalam diri yang tinggi untuk mengakses atau bermain video game berunsur kekerasan mendapatkan kebebasan saat di sekolah.

Selanjutnya, untuk melihat adanya perbedaan pengaruh yang signifikan maka dilakukan analisis menggunakan uji Kruskall-Wallis. Terima hipotesis terjadi jika nilai probabilitas (pvalue) yang dihasilkan dari uji ini kurang dari taraf nyata yang digunakan yaitu $5 \%$. Terima hipotesis berarti cukup bukti untuk menyatakan bahwa terdapat perbedaan pengaruh tingkat perilaku bermain video game berunsur kekerasan antara tingkat pembatasan situasional sangat rendah, rendah, tinggi dan sangat tinggi yang diperoleh dari perhitungan tingkat pembatas dari orang tua, tingkat ajakan teman sebaya, dan tingkat pengetahuan.

Tabel 10 Hasil uji statistik perbedaan tingkat perilaku bermain video game berunsur kekerasan berdasarkan tingkat situasional

\begin{tabular}{cc}
\hline Uji statistik & $\begin{array}{c}\text { Perilaku bermain video game } \\
\text { berunsur kekerasan }\end{array}$ \\
\hline Chi-Square & 24.165 \\
p-value & 0.000
\end{tabular}

Sumber: hasil uji Kruskall-wallis

Berdasarkan hasil uji Kruskall-wallis diperoleh nilai probabilitas ( $p$-value) sebesar 0.000 . Nilai probabilitas (p-value) yang dihasilkan dari uji ini kurang dari taraf nyata yang digunakan yaitu 5\% atau 0.05 maka hipotesis diterima yang berarti terdapat perbedaan pengaruh tingkat perilaku bermain video game berunsur kekerasan antara tingkat situasional sangat rendah, rendah, tinggi dan sangat tinggi yang diperoleh dari perhitungan tingkat pembatas dari orang tua, tingkat ajakan teman sebaya, dan tingkat 
pengetahuan pada taraf nyata 5\%. Ringkasnya, tingkat situasional sangat rendah, rendah, tinggi dan sangat tinggi mempengaruhi perilaku bermain video game berunsur kekerasan. Hasil yang diperoleh sesuai dengan teori yang mengatakan bahwa perilaku remaja dipengaruhi oleh faktor lingkungan.

Menurut Yusuf (2011), faktor lingkungan yang dapat mempengaruhi perkembangan individu adalah lingkungan fisik, psikis, sosial dan religius. Faktor lingkungan yang dimaksud meliputi lingkungan keluarga, sekolah, dan kelompok teman sebaya. Lingkungan keluarga merupakan lingkungan yang pertama bagi remaja untuk mengajarkan norma dan nilai serta lingkungan yang pertama kali yang memberikan remaja pengetahuan dan informasi terkait lingkungan disekitarnya. Pentingnya pengawasan dari orang tua atau keluarga dalam memberikan batasan untuk berperilaku bermian video game berunsur kekerasan dan perlunya kegiatan yang dapat membuat remaja memiliki kemampuan untuk menyeleksi game untuk mereka konsumsi baik dari lingkungan keluarga maupun dari lembaga pendidikan dapat mempengaruhi pengetahuan dan perilaku remaja dalam bermain video game.

Remaja juga tidak terlepas dari pengaruh temanteman di sekitarnya. Menurut Hurlock (1980) pengaruh teman-teman sebaya pada sikap, pembicaraan, minat, penampilan, dan perilaku lebih besar daripada pengaruh keluarga. Selanjutnya, remaja tidak lagi memilih teman berdasarkan kemudahannya di sekolah atau di lingkungan tetangga sebagaimana halnya pada masa kanak-kanak, dan kegemarannya pada kegiatan-kegiatan yang sama, namun remaja menginginkan teman yang mempunyai minat dan nilai-nilai yang sama, yang dapat mengerti dan membuatnya merasa aman, dapat mempercayakan masalah-masalah dan membahas hal-hal yang tidak dapat dibicarakan dengan orang tua dan guru. Teman dekat saling mempengaruhi satu sama lain meskipun kadangkadang juga bertengkar.

\section{Analisis Perbedaan Pengaruh Tingkat Perilaku Agresi Remaja berdasarkan Tingkat Perilaku Bermain Video Game Berunsur Kekerasan}

Salah satu dugaan dampak negatif dari bermain video game adalah terjadinya perubahan perilaku agresi yang akan muncul pada remaja. Menurut Myers (2012) mendefinisikan agresi (aggression) sebagai perilaku fisik atau verbal yang bertujuan untuk menyakiti orang lain. Perbedaan pengaruh perilaku bermain video game berunsur kekerasan dapat dilihat pada Tabel 16.

Tabel 11 Perilaku agresi remaja berdasarkan tingkat perilaku bermain video game berunsur kekerasan

\begin{tabular}{cccccc}
\hline \multicolumn{5}{c}{ berunsur kekerasan } \\
Perilaku & \multicolumn{4}{c}{$\begin{array}{c}\text { Perilaku bermain video game } \\
\text { berunsur kekerasan }\end{array}$} & \multirow{2}{*}{ Jumlah } \\
\cline { 2 - 5 } & $\begin{array}{c}\text { Sangat } \\
\text { rendah }\end{array}$ & Rendah & Tinggi & $\begin{array}{c}\text { Sangat } \\
\text { tinggi }\end{array}$ & \\
\hline Sangat & 7 & 16 & 9 & 1 & 33 \\
rendah & 2 & 37 & 11 & 1 & 51 \\
Rendah & 2 & 2 & 3 & 0 & 5 \\
Tinggi & 0 & 0 & 1 & 0 & 1 \\
Sangat & 0 & 55 & 24 & 2 & 90 \\
Tinggi & 9 & 55 & & & \\
\hline Jumlah & 9 &
\end{tabular}

Tabel 11 menunjukkan perbedaan tingkat perilaku agresi remaja turut ditentukan oleh perbedaan intensitas perilaku bermain video game berunsur kekerasan. Berdasarkan pada tabel tersebut bahwa sebanyak 9 responden dengan tingkat perilaku bermain video game berunsur kekerasan yang sangat rendah hanya 7 responden yang tergolong pada perilaku agresi yang sangat rendah, dan 2 responden yang tergolong pada perilaku agresi rendah. Selanjutnya, terdapat 55 responden dengan tingkat perilaku bermain video game berunsur kekerasan yang rendah memiliki 37 responden dengan perilaku agresi yang rendah, 16 responden menunjukkan perilaku agresi yang sangat rendah, 2 responden menunjukkan perilaku agresi yang tinggi dan tidak ada responden yang tergolong pada perilaku agresi yang sangat tinggi.

Pada perilaku bermain video game berunsur kekerasan yang tinggi, dari 24 responden hanya terdapat 1 responden dengan tingkat perilaku agresi yang tergolong sangat tinggi, 3 responden dengan tingkat perilaku agresi yang tinggi, 11 responden dengan tingkat perilaku agresi yang rendah, dan 9 responden dengan tingkat perilaku agresi sangat rendah. Akan tetapi, hanya 2 responden saja dengan tingkat perilaku bermain video game berunsur kekerasan sangat tinggi memiliki tingkat agresi yang rendah dan sangat 
rendah. Dari data tersebut dapat disimpulkan bahwa semakin tinggi tingkat perilaku bermain video game berunsur kekerasan maka semakin tinggi tingkat perilaku agresi remaja. Akan tetapi, sebanyak 20 responden dengan tingkat perilaku bermain video game berunsur kekerasan tergolong tinggi dan 2 responden tergolong sangat tinggi namun menunjukkan tingkat perilaku agresi yang tergolong rendah. Hal ini disebabkan oleh faktor lain yang mempengaruhi responden diluar faktor situasional yang diteliti dalam penelitian ini seperti nilai-nilai agama yang ada dalam diri responden baik diperoleh dari lingkungan sekolah seperti mengikuti kegiatan Rohis (Rohani Islami) dan Keputrian yang ada di lingkungan sekolah maupun nilainilai dan norma yang ada dalam keluarga seperti dituntut untuk sopan santun, ramah, lemahlembut sehingga mencegah terjadinya tindakan untuk menyakiti orang lain.

Selanjutnya, untuk melihat adanya perbedaan pengaruh yang signifikan maka dilakukan analisis menggunakan uji Kruskall-Wallis. Terima hipotesis terjadi jika nilai probabilitas (pvalue) yang dihasilkan dari uji ini kurang dari taraf nyata yang digunakan yaitu $5 \%$. Terima hipotesis berarti cukup bukti untuk menyatakan bahwa terdapat perbedaan pengaruh tingkat perilaku agresi remaja antara tingkat perilaku bermain video game berunsur kekerasan intensitas sangat rendah, intensitas rendah, intensitas tinggi, dan intensitas sangat tinggi pada taraf nyata $5 \%$.

Tabel 12 Hasil uji statistik perbedaan tingkat agresivitas remaja berdasarkan intensitas bermain video game berunsur kekerasan

\begin{tabular}{cc}
\hline Uji statistik & $\begin{array}{c}\text { Perilaku bermain video } \\
\text { game berunsur kekerasan }\end{array}$ \\
Chi-Square & 9.240 \\
p-value & 0.026 \\
\hline Sumber: hasil uji Kruskall-wallis &
\end{tabular}

Berdasarkan hasil uji Kruskall-wallis diperoleh nilai probabilitas (p-value) sebesar 0.026. Nilai probabilitas (p-value) yang dihasilkan dari uji ini kurang dari taraf nyata yang digunakan yaitu $5 \%$ atau 0.05 maka hipotesis diterima yang berarti terdapat perbedaan pengaruh tingkat perilaku agresi remaja antara tingkat perilaku bermain video game berunsur kekerasan intensitas sangat rendah, intensitas rendah, intensitas tinggi, dan intensitas sangat tinggi pada taraf nyata 5\%. Tingkat perilaku bermain video game berunsur kekerasan mempengaruhi tingkat agresivitas remaja. Hasil yang diperoleh sesuai dengan teori yang diungkapkan oleh Myers (2012) bahwa pengaruh media yang dapat mempengaruhi perilaku agresi seseorang salah satunya adalah video game.

Gentile dan Anderson dalam Myers (2012), Milla [tahun tidak diketahui] mengungkapkan bahwa kekuatan pengaruh media audio visual disebabkan media jenis ini tidak hanya mampu mengoptimalkan pesan melalui pendengaran, melainkan juga penglihatan dan gerakan sekaligus, dimana pesan bergerak memiliki daya tarik lebih dibandingkan pesan statis. Hasil penelitian ini juga selaras dengan dampak video game berunsur kekerasan yang diungkapkan oleh Anderson dan Bushman (2001) dalam Myers (2012) bahwa video game berunsur kekerasan meningkatkan keterbangkitan fisik, pikiran agresif, perasaan agresif, dan perilaku agresif.

\section{KESIMPULAN DAN SARAN}

\section{Kesimpulan}

Semakin tinggi tingkat perilaku bermain video game berunsur kekerasan maka semakin tinggi juga tingkat perilaku agresi remaja. Sebaliknya, semakin rendah tingkat perilaku bermain video game berunsur kekerasan maka semakin rendah juga tingkat perilaku agresi remaja. Jadi, terdapat perbedaan pengaruh tingkat bermain video game berunsur kekerasan terhadap tingkat perilaku agresi remaja.

Responden laki-laki cenderung memiliki tingkat perilaku bermain video game berunsur kekerasan yang tergolong lebih tinggi daripada responden perempuan. Jadi, terdapat perbedaan pengaruh faktor personal sebagai pembentuk perilaku bermain video game berunsur kekerasan terhadap tingkat perilaku agresi remaja.

Responden dengan tingkat situasional yang rendah untuk bermain video game berunsur kekerasan cenderung memiliki tingkat perilaku bermain video game berunsur kekerasan yang relatif rendah, sedangkan responden dengan tingkat situasional yang relatif tinggi untuk bermain video game berunsur kekerasan 
cenderung memiliki tingkat perilaku bermain video game yang tinggi.

\section{Saran}

1. Pemerintah Indonesia sebaiknya memperhatikan isi dari video game yang dapat dimainkan oleh para remaja baik itu game online maupun game offline agar tidak mengarahkan remaja pada perilaku agresi

2. Pihak sekolah sebaiknya menghimbau anakanak untuk tidak bermain video game berunsur kekerasan secara berlebihan atau terus menerus serta mengajak orangtua untuk turut serta dalam mengawasi segala aktivitas anak.

3. Orangtua sebaiknya lebih waspada dan lebih ketat dalam memberikan kebebasan anaknya untuk bermain video game dan memberikan pengawasan terhadap ajakan teman sebayanya untuk bermain video game di luar rumah.

4. Perlunya penelitian yang sama dengan mengambil responden lebih banyak khususnya remaja-remaja yang benar-benar terlibat dalam perilaku-perilaku kekerasan yang sudah mengarah pada kriminalitas.

\section{DAFTAR PUSTAKA}

Daniel WW. 1990. Applied Nonparametric Statistics. Boston : PWS-KENT Publishing Company.

Dariyo A. 2004. Psikologi Perkembangan Remaja. Bogor (ID): Ghalia Indonesia.

Gentilea DA, Lynch PJ, Linderc JR, Walsh DA. 2004. The effects of violent video game habits on adolescent hostility, aggressive behaviors, and school performance. Journal of Adolescence. [internet]. [diunduh pada tanggal 28 Februari 2014]. 27:5-22. Dapat diunduh dari: http://www.google.com/ url? $\mathrm{sa}=\mathrm{t} \& \mathrm{rct}=\mathrm{j} \& \mathrm{q}=\&$ esrc $=\mathrm{s} \&$ source $=$ web $\& \mathrm{~cd}=7 \&$ ved $=0$ CGIQFjAG\&url=http $\% 3 \mathrm{~A}$ $\% 2 \mathrm{~F} \% 2 \mathrm{Fdrdouglas} .0 \mathrm{rg} \% 2 \mathrm{Fdrdpdfs} \% 2 \mathrm{FGe}$ ntile_Lynch_Linder_Walsh_2004.pdf\&ei= wCMQUU6jqOY_SrQ'fAsYDQ_\&usg=AFQj CNFELsUpDUMuMfSEkdZxwkiGuNdDd w atau doi:10.1016/ j.adolescence.2003.10.002

Hurlock EB. 1980. Psikologi Perkembangan Suatu Pendekatan: Sepanjang Rentang Kehidupan. Istiwidayanti, Soedjarwo, penerjemah; Ridwan MS, editor. Jakarta
(ID): Penerbit Erlangga. Terjemahan dari: Development Psycology: A Life-Span Approach. Ed ke-5.

Haryatmoko. 2007. Etika Komunikasi. Yogyakarta (ID): Kanisius.

Kurniawati Y. 2010. Hubungan bermain game online terhadap perilaku agresif remaja. [skripsi]. [internet]. [diunduh pada tanggal 26 September 2013]. [Universitas Katolik Soegijapranata]. Dapat

diunduh dari: http://eprints.unika.ac.id/3189/1/05.40.004 0 Yulia_Kurniawati.pdf

Malahayati D. 2012. Hubungan kebiasaan bermain video game dengan tingkat motivasi belajar pada anak usia sekolah. [skripsi]. [internet]. [diunduh pada tanggal 4 Februari 2015]. [Universitas Indonesia]. Dapat diunduh dari: http://www.google.com/url?sa=t\&rct=j\&q $=$

\&esrc $=$ s\&source $=$ web $\& c d=4 \&$ cad $=r j a \& u a$ $\mathrm{ct}=8 \&$ ved $=0 \mathrm{CC} 8 \mathrm{QFj} A D \& u r l=\mathrm{http} \% 3 \mathrm{~A} \% 2$ F\%2Flib.ui.ac.id\%2Ffile\%3Ffile\%3Ddigit al\%2F20308696-S42742Hubungan\%2520 kebiasaan.pdf\&ei=qvvRVOqQKcuyuASzu YLIDQ\&usg=AFQjCNFZprOuxZYVFLV Hnt0ZpMMrzLpsgw\&sig2=BzhaO2Wk63 51S4cIutFbeA\&bvm=bv.85076809,d.c2E

Milla MN. [tahun tidak diketahui]. Pengaruh terpaan kekerasan media audio-visual pada kognisi agresif dan afeksi agresif studi meta-analisis. Jurnal Psikologi. [internet]. [diunduh pada tanggal 26 September 2013]. 33(2):1-16. Dapat diunduh dari: http://jurnal.psikologi.

ugm.ac.id/index.php/fpsi/article/view/84/7 4

Myers DG. 2012. Psikologi Sosial. Jakarta (ID): Salemba Humanika.

Nando. 2011. Hubungan antara perilaku menonton film kartun yang mengandung kekerasan di televisi dengan perilaku agresi pada anak (kasus remaja di SMK Pelita, Kecamatan Ciampea, Kabupaten Bogor, Provinsi Jawa Barat). [skripsi]. [internet]. [diunduh pada tanggal 26 Februari 2014]. [Institut Pertanian Bogor]. Dapat diunduh dari: http://dosen. narotama.ac.id/wpcontent/uploads/2012/03 / HUBUNGAN-ANTARA-PERILAKUMENONTON-FILM-KEKERASAN- 


\section{DENGAN-PERILAKU-AGRESI-}

REMAJA.pdf

Nashori HF. 2008. Psikologi Sosial Islami. Bandung (ID): PT Refika Aditama.

Nurihsan J dan Agustin M. 2011. Dinamika Perkembangan Anak dan Remaja: Tinjauan Psikologi, Pendidikan, dan Bimbingan. Bandung (ID): PT Refika Aditama.

Santrock JW. 2007. Perkembangan Anak. Jakarta (ID): Erlangga.

Video game picu kekerasan?. 20136 Feb. [internet]. [diunduh 24 Oktober 2013]. Femina. Dapat diunduh dari: http://www. femina.co.id/isu.wanita/topik.hangat/video. game.picu.kekerasan/005/007/226

Vivian J. 2008. Teori Komunikasi Massa Edisi Kedelapan. Jakarta (ID): Kencana. 658 hal.

Widyastuti. 1996. Hubungan antara menonton film kekerasan di televisi dengan tingkat agresivitas penonton. [tesis]. Depok (ID): Universitas Indonesia.

Yusuf SLN. 2011. Psikologi Perkembangan Anak dan Remaja. Bandung (ID): PT Remaja Rosdakarya Offset.

Zulkifli NI. 2013. Efek game online terhadap tindakan kekerasan anak jalanan. Jurnal $P E K O M M A S$. [internet]. [diunduh pada tanggal 28 Februari 2014]. 16(1):35-40. Dapat diunduh dari: http://www. google.

com/url? sa $=$ t\&rct $=\mathrm{j} \& \mathrm{q}=\&$ esrc $=\mathrm{s} \&$ source $=$ web\&cd $=15 \& \mathrm{cad}=$ rja\&uact $=8 \& \mathrm{ved}=0 \mathrm{CEg}$ QFjAEOAo\&url=http\%3A\%2F\%2Fjurnal. kominfo.go.id\%2Findex.php\%2Fpekomma s\%2Farticle\%2Fdownload\%2F137\%2F126 \&ei=bx00U8aDHIaKrQfzqIFw\&usg=AFQ jCNFxiHrGBWbciXMJLNqxntIrQrdimw \&bvm=bv.63808443,d.bmk 